\title{
The Role of Plant Characteristics in the Resistance of White Cabbage to Onion Thrips: Preliminary Results
}

\author{
J. FAIL ${ }^{1} *$ J. ZANA ${ }^{2}$ and B. PÉNZES ${ }^{1}$ \\ ${ }^{1}$ Department of Entomology, Faculty of Horticultural Science, Corvinus University of Budapest, \\ Ménesi út 44, H-1118 Budapest, Hungary \\ ${ }^{2}$ Department of Physics and Control, Faculty of Food Science, Corvinus University of Budapest, \\ Somlói út 14-16, H-1118 Budapest, Hungary
}

(Received: 4 March 2008; accepted: 6 June 2008)

\begin{abstract}
The onion thrips, Thrips tabaci Lindeman (Thysanoptera: Thripidae) has been recognized as a severe worldwide pest of white cabbage (Brassica oleracea L. convar. capitata provar. capitata Duch.) for almost three decades. Although the most effective control measure is the use of resistant varieties, little is known about the resistance mechanism(s) involved. In 2007, a study at Tordas, Hungary, was carried out with 6 varieties to confirm that antixenosis is at least partly responsible for the resistance against onion thrips. The number of adult thrips and their progeny was counted on the outer ten head leaves at one-third of the heading process. At the same time, the light reflectance of old and outer head leaves was measured. The onion thrips damage was also assessed at full maturity. Antixenosis was found to be responsible for the resistance of 'Balashi', 'Bloktor' and 'Riana' varieties, since the number of adults and offspring found on head leaves was significantly lower than that of 'Green gem', 'Hurricane' and 'Quisto'. The resistant varieties ('Balashi', 'Bloktor' and 'Riana') similarly suffered significantly lower damage than the susceptible ones ('Green gem', 'Hurricane' and 'Quisto'). The light reflectance spectra of all six varieties were almost identical in the case of the old leaves, but a difference was found between the susceptible and resistant varieties when the reflectance of the outer head-forming leaves was measured. Similarly, the colour of the old leaves was not greatly different, but that of the outer head-forming leaves was correlated to the number of thrips adults found in the cabbage heads.
\end{abstract}

Keywords: white cabbage, Thrips tabaci, onion thrips, antixenotic resistance, light reflectance, leaf colour.

The onion thrips, Thrips tabaci Lindeman (Thysanoptera: Thripidae) has been recognized as a serious threat to white cabbage production in the USA (Shelton et al., 1982, 1983), Germany (Dalchow and Dern, 1983; Giessmann, 1988), the Netherlands (Kretschmer, 1984), Hungary (Kristóf L.né and Pénzes, 1984), Jordan (Mustafa, 1986), Austria (Kahrer, 1992), France (Herold and Stengel, 1993), Switzerland, Austria and England (Ellis et al., 1994), Poland (Legutowska, 1997) and Slovenia (Trdan et al., 2004).

Thrips injury appears as bronze discoloration and rough texture on the head leaves and results in cabbage that does not meet fresh market standards (North and Shelton, 1986a). According to North and Shelton (1986b), all stages of thrips can be found in the first 11 leaf layers of mature cabbage heads. However, sometimes the symptoms of infes- 
tation occur down to the 38th leaf of the head (Legutowska, 1997). After head formation has started, onion thrips may colonize the cabbage plant in mass from other hosts, including different cereal crops, alfalfa, red clover (Shelton and North, 1986), and amongst many others also from all kinds of onion. The possible role of cereals as a reservoir for the onion thrips is questioned by Kahrer (1994), who found no evidence of early development on cereal crops prior to mass invasion of cabbage.

The use of insecticides usually results in poor control of onion thrips on cabbage (Andaloro et al., 1983), and the release of predatory mites on cabbage fields does not give adequate control either (Hoy and Glenister, 1991). Based on extensive research, Stoner and Shelton (1988a) stated that the timing of planting is a possible means of protection, as it can reduce thrips damage but the primary control of thrips damaging cabbage should be the selection of tolerant varieties (Shelton et al., 1998). Field trials have been carried out in order to assess the resistance of several cabbage varieties against onion thrips. The screening method has been based on either the extent of the injury observed on leaves (Kristóf L.né et al., 1988; Pénzes and Szani, 1990, 1992a, b; Pénzes et al., 1996, 1998, 2000), or on both the extent of the injury and the number of thrips collected (Shelton et al., 1983, 1988; Stoner and Shelton, 1988b).

Very few studies have been carried out with cabbage varieties in order to identify the patterns of resistance against onion thrips. Since Painter (1941), three mechanisms of resistance have been defined: nonpreference, antibiosis and tolerance. Later on, antixenosis was proposed to be used instead of the former term, nonpreference (Kogan and Ortman, 1978).

Up to now, the only trial on antixenotic resistance of cabbage varieties against onion thrips under field conditions as well as in the laboratory was carried out by Stoner and Shelton (1988c). Although in the leaf disk array onion thrips showed no preference for any of the varieties, in the field tests the number of thrips collected from head leaves and that from frame leaves were significantly different. No plant characteristics were identified as responsible for the resistance. In a later study moderate negative correlation was found between the epicuticular wax content of cabbage head leaves and the damage onion thrips caused (Trdan et al., 2004). Thrips susceptibility of cabbage cultivars seems to be negatively correlated with head firmness as well (Trdan et al., 2005).

Our primary goal in this study was to confirm that antixenosis does play a role in the resistance of white cabbage to onion thrips and to assess the effect of cabbage leaf colour on host acceptance of onion thrips.

\section{Materials and Methods}

The experiments were carried out at the Tordas Station of the Central Agricultural Office in 2007, Tordas, Hungary. Greenhouse-grown seedlings of 6 varieties ('Balashi', 'Bloktor', 'Green gem', 'Hurricane', 'Quisto' and 'Riana') were transplanted outdoors on the 18th of April 2007 in order to assure high onion thrips damage pressure during head formation. Plots were composed of 7 rows of 13 plants, spaced 0.6 by $0.6 \mathrm{~m}$ apart. These plots were replicated four times in a randomised block design with an alleyway of $3 \mathrm{~m}$ separat- 
ing replicates. Standard herbicide, fertilization and irrigation practices were employed. Plants were treated with pesticides against pests and diseases. Head formation started in the second half of May (Table 1).

\section{Antixenotic evaluation}

Three to five weeks after cupping had started (Table 1) in the small cabbage heads the number of adult thrips was counted. For every cabbage variety twelve heads from each block were transported to the laboratory (dates are given in Table 1 under the 'Antixenotic evaluation' column) and kept in plastic bags at room temperature until the antixenotic evaluation was completed. The first ten outer head leaves were removed one after the other and the number of adult thrips on both sides was counted under a stereomicroscope. The combined number of adult thrips on all ten leaves was used in statistical analysis describing the number of adults in a given cabbage head. Varieties were compared pairwise by the GamesHowell test.

At the same time, three heads from each block were also transported to the laboratory for counting thrips eggs and emergence holes. The assessment and statistical analysis was carried out as described above for adult counting but the cabbage leaves were illuminated from underneath in order to make inserted eggs and emergence holes visible under a stereomicroscope.

In parallel with the thrips counting, the light reflectance of old cabbage leaves and the outer head-forming leaves was measured using a Hunterlab Ultrascan 8009 spectrocolorimeter. The instrument was set in reflectance mode as described here: large area of view - round opening with a diameter of $32.4 \mathrm{~mm}$; mounted without UV light source, total reflectance, specular included (mirroring effect); calibrated using the standard method: light trap, white and grey officially calibrated standards. Three old and three outer head-forming cabbage leaves from each block were transported to the laboratory and their light reflectance was measured within hours. Four measurements were performed at different spots

Table 1

Start of head formation and timetable of evaluations

\begin{tabular}{|c|c|c|c|c|c|c|}
\hline \multirow{2}{*}{ Variety } & \multicolumn{2}{|c|}{ Cupping starts } & \multicolumn{2}{|c|}{ Antixenotic evaluation } & \multicolumn{2}{|c|}{ Damage assessment } \\
\hline & date & d.a.t.* & date & d.a.c. $* *$ & date & d.a.c. $* *$ \\
\hline ‘Balashi' & 18th of May & 31 & 18th of June & 31 & 9th of July & 52 \\
\hline 'Bloktor' & 29th of May & 42 & 2nd of July & 34 & 4th of September & 98 \\
\hline ‘Green gem' & 17th of May & 30 & 6 th of June & 20 & 9th of July & 53 \\
\hline 'Hurricane' & 24th of May & 37 & 26th of June & 33 & 6th of August & 74 \\
\hline ‘Quisto’ & 18th of May & 31 & 14th of June & 27 & 10th of July & 53 \\
\hline 'Riana’' & 18th of May & 31 & 20th of June & 33 & 10th of July & 53 \\
\hline
\end{tabular}

*: d.a.t. $=$ days after transplantation, $* *$ : d.a.c. $=$ days after cupping started 
of a single leaf from old leaves on the upper side, whereas from outer head-forming leaves these measurements were made on the underside (which is actually seen from above due to the morphology of the cabbage head). Light reflectance spectra were measured from $380 \mathrm{~nm}$ to $750 \mathrm{~nm}$ at $10 \mathrm{~nm}$ intervals and colorimetric data were calculated by the original software belonging to the instrument in CIE 1931 XYZ system and in the CIE 1976 L*a*b* system, computed according to the two degrees standard observer and the $\mathrm{C}$ standard illuminant (correlated colour temperature of $6774 \mathrm{~K}$ ). Statistical analysis was performed on CIE $1976 a^{*}$ and $b^{*}$ values and varieties were compared pairwise by the Tukey-Kramer test.

\section{Damage assessment}

Onion thrips damage assessment was carried out at harvest maturity of the varieties (exact dates are given in Table 1 under the 'Damage assessment' column). Twelve heads were taken from each block. For the assessment of thrips damage (the result of spontaneous thrips infestation) an evaluation method was developed (Fail, 2006). Cabbage head leaves are evaluated and peeled off the head one after the other until four consecutive leaves show no damage. For every examined head-forming leaf the extent of damage is noted (only on the underside of the leaves) in the form of the proportion of damaged surface to the entire surface of the leaf: from 0 to 1 with an accuracy of 0.1 . Varietal resistance is represented by the sum of these values expressing the damage observed in the whole head. A given figure expresses the size of the total damaged leaf surface in the entire cabbage head in proportion to the size of the underside of the first head-forming leaf. Statistical analysis was performed on these figures, and varieties were compared pairwise by the Games-Howell test.

\section{Results}

\section{Antixenotic evaluation}

Significant differences were found between the varieties in the number of adult thrips counted in cabbage heads (Table 2). There was a strong positive correlation between the number of adult thrips and the damage ratings (Pearson's $r=0.64$, significance: $p<0.001$ ).

Significant differences in the combined number of eggs and emergence holes between the varieties were found (Table 3). Both larval and pupal stages of thrips were found on the leaves, but newly emerged adults were lacking. The combined figure for moving immature stages was roughly equal to the number of emergence holes in a given cabbage head. A strong positive correlation between the number of thrips offspring and the damage ratings (Pearson's $r=0.533$, significance: $p<0.001$ ) was found.

Significant differences in the CIE $1976 \mathrm{a}^{*}$ and $\mathrm{b}^{*}$ values between the varieties (Table 4) were found. In the case of the old leaves, no correlation was found between these variables and the number of adult thrips in the cabbage heads. Basically, the variety 'Bloktor' was different from the other varieties. But in the case of the outer head leaves moderate cor- 
Table 2

Number of adult thrips in white cabbage heads

\begin{tabular}{|c|c|c|c|c|c|}
\hline \multirow{2}{*}{ Variety } & \multirow{2}{*}{$\begin{array}{c}\text { Date } \\
\text { of assessment }\end{array}$} & \multirow{2}{*}{ Mean } & \multirow{2}{*}{ Significance* } & \multicolumn{2}{|c|}{$95 \%$ Confidence interval } \\
\hline & & & & Lower bound & Upper bound \\
\hline 'Hurricane' & 26th of June & 20.6 & a & 17.8 & 23.4 \\
\hline 'Quisto' & 14th of June & 7.8 & $\mathrm{~b}$ & 6.5 & 9.2 \\
\hline 'Green gem' & 6 th of June & 7.8 & $\mathrm{~b}$ & 6.6 & 9.0 \\
\hline 'Bloktor' & 2nd of July & 3.9 & $\mathrm{c}$ & 3.1 & 4.8 \\
\hline 'Riana’ & 20th of June & 0.8 & d & 0.5 & 1.1 \\
\hline 'Balashi' & 18th of June & 0.5 & d & 0.3 & 0.7 \\
\hline
\end{tabular}

*: means with different letters are significantly different from each other by the Games-Howell test, $p<0.0001$

Table 3

Number of thrips offspring (eggs + emergence holes) in white cabbage heads

\begin{tabular}{llcccc}
\hline \multirow{2}{*}{ Variety } & \multicolumn{1}{c}{$\begin{array}{c}\text { Date } \\
\text { of assessment }\end{array}$} & Mean & Significance* & \multicolumn{2}{c}{ 95\% Confidence interval } \\
\cline { 5 - 6 } 'Hurricane' & 26th of June & 495.9 & a & 343.55 & 648.29 \\
'Quisto' & 14th of June & 72.5 & b & 35.77 & 109.23 \\
'Green gem' & 6th of June & 11.3 & c & 5.58 & 17.08 \\
'Bloktor' & 2nd of July & 12.0 & cd & 3.83 & 20.17 \\
'Riana' & 20th of June & 0.5 & d & 0.00 & 1.01 \\
'Balashi' & 18th of June & 0.3 & d & 0.00 & 0.74 \\
\hline
\end{tabular}

*: means with different letters are significantly different from each other by the Games-Howell test, $p<0.05$

Table 4

Colorimetric characteristics of cabbage leaves

\begin{tabular}{|c|c|c|c|c|c|c|c|c|c|}
\hline \multirow{3}{*}{ Variety } & \multirow{3}{*}{$\begin{array}{c}\text { Date } \\
\text { of measurement }\end{array}$} & \multicolumn{4}{|c|}{ Old leaves } & \multicolumn{4}{|c|}{ Outer head-forming leaves } \\
\hline & & \multicolumn{2}{|c|}{ CIE $1976 a^{*}$ value } & \multicolumn{2}{|c|}{ CIE $1976 b^{*}$ value } & \multicolumn{2}{|c|}{ CIE $1976 a^{*}$ value } & \multicolumn{2}{|c|}{ CIE 1976 b* value } \\
\hline & & Mean & Sign.* & Mean & Sign.* & Mean & Sign.* & Mean & Sign.* \\
\hline 'Hurricane' & 26th of June & -7.2 & $\mathrm{bc}$ & 7.8 & $\mathrm{a}$ & -13.2 & $\mathrm{bc}$ & 22.7 & $\mathrm{a}$ \\
\hline 'Quisto' & 14 th of June & -7.3 & $\mathrm{bc}$ & 7.7 & $\mathrm{a}$ & -13.3 & $\mathrm{c}$ & 22.6 & a \\
\hline 'Green gem' & 6 th of June & -7.2 & $\mathrm{~b}$ & 7.5 & $\mathrm{a}$ & -12.8 & $\mathrm{~b}$ & 21.4 & $\mathrm{a}$ \\
\hline 'Bloktor' & 2nd of July & -6.4 & $\mathrm{a}$ & 5.0 & $\mathrm{~b}$ & -11.1 & $\mathrm{a}$ & 16.0 & $\mathrm{~b}$ \\
\hline 'Balashi' & 18th of June & -7.6 & $\mathrm{bc}$ & 7.7 & $\mathrm{a}$ & -11.5 & $\mathrm{a}$ & 14.9 & $\mathrm{bc}$ \\
\hline 'Riana' & 20th of June & -7.6 & $\mathrm{c}$ & 8.3 & $\mathrm{a}$ & -11.1 & $\mathrm{a}$ & 13.9 & $\mathrm{c}$ \\
\hline
\end{tabular}

*: means with different letters are significantly different from each other by the Tukey-Kramer test, $p<0.01$ 
relation was found between the colorimetric values and the number of adult thrips in the cabbage heads (CIE 1976 a*: Pearson's $r=-0.477$ significance: $p<0.001$, CIE 1976 b*: Pearson's $r=0.519$, significance: $p<0.001$ ). The colour of head leaves of susceptible varieties was yellowish whereas that of the resistant ones was yellowish green.

\section{Damage assessment}

Significant differences in thrips damage between the varieties were found (Table 5). Resistance of a variety is proven by these damage ratings. Varieties with the highest figures are considered susceptible ('Green gem', 'Hurricane' and 'Quisto') and those with lower ones are referred to as resistant ('Balashi' and 'Riana') or moderately resistant ('Bloktor').

Table 5

Thrips damage ratings in white cabbage heads

\begin{tabular}{llcccc}
\hline \multirow{2}{*}{ Variety } & \multicolumn{1}{c}{$\begin{array}{c}\text { Date } \\
\text { of assessment }\end{array}$} & Mean & Significance* & \multicolumn{2}{c}{ 95\% Confidence interval } \\
\cline { 5 - 6 } 'Hurricane' & 6th of August & 5.4 & a & Lower bound & Upper bound \\
'Green gem' & 9th of July & 4.9 & $\mathrm{a}$ & 4.99 & 5.77 \\
'Quisto' & 10th of July & 3.1 & $\mathrm{~b}$ & 2.77 & 5.27 \\
'Bloktor' & 4th of September & 1.8 & $\mathrm{c}$ & 1.56 & 3.40 \\
'Riana' & 10th of July & 0.2 & $\mathrm{~d}$ & 0.14 & 1.94 \\
'Balashi' & 9th of July & 0.1 & $\mathrm{e}$ & 0.06 & 0.19 \\
\hline
\end{tabular}

*: means with different letters are significantly different from each other by the Games-Howell test, $p<0,001$

\section{Discussion}

The use of a continuous ratio type variable for damage assessment of cabbage varieties in this study instead of the widely used discrete ordinal type variable, such as the various damage rating scales, makes the statistical analysis simple and means that the results are easily interpretable. The original variable - the rate of damage - is a continuous ratio type variable, but for the sake of quick damage assessment the use of an artificial damage rating scale, which is often a discrete ordinal type variable, is widely accepted. But this sacrifice is unnecessary because the assessment process used in this study was found to be just as quick as with a damage rating scale.

The level of resistance of the tested varieties in this study was quite similar to their previous evaluations (Fail et al., 2002, 2003; Garamvölgyi et al., 2004; Fail, 2006). The colonization of cabbage heads by thrips seems to be correlated with varietal thrips resistance. The number of thrips adults and their progeny found in small cabbage heads was significantly greater on susceptible varieties than on resistant ones (evaluated three to five weeks after heading had started). Therefore, it is concluded that the resistance of 'Balashi', 


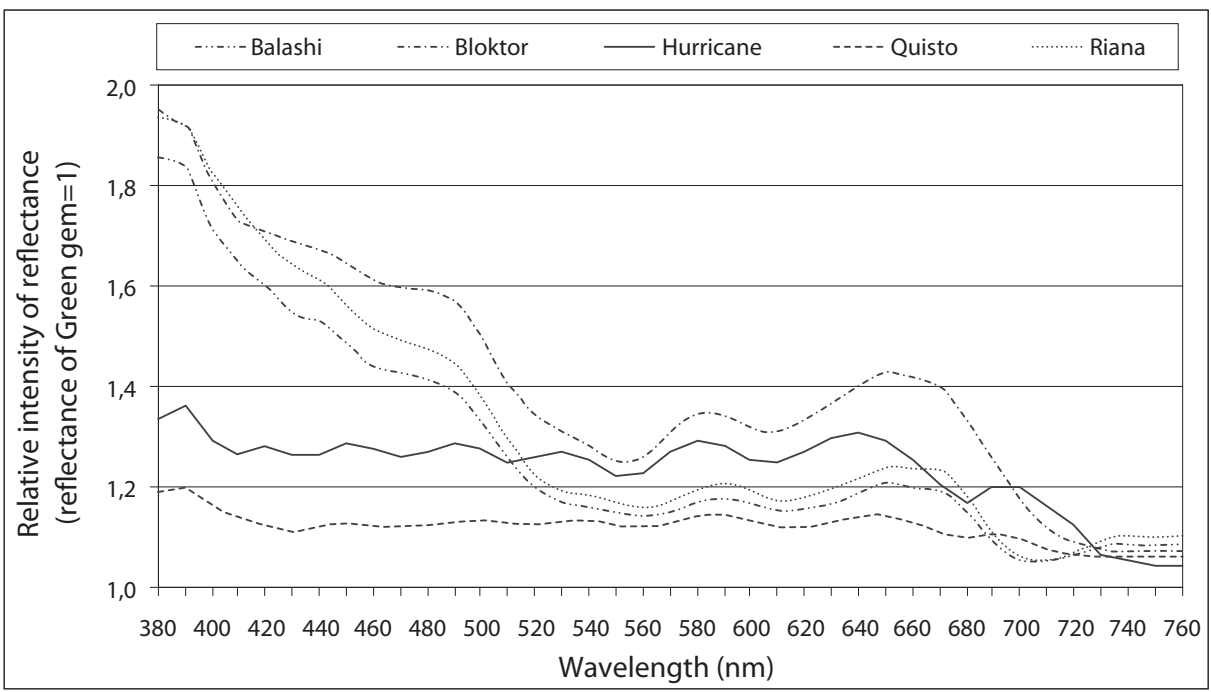

Fig. 1. Reflectance spectra of cabbage outer head leaves

'Bloktor' and 'Riana' varieties to onion thrips is at least partly antixenotic since they are discriminated by the thrips as hosts.

What plant characteristics make the thrips prefer one variety to another? Perhaps some plant characteristics that are perceivable before landing, like scent or light reflectance of the host. Perhaps some plant characteristics that are perceivable only after landing, like physical and chemical parameters of the epidermis or chemical constitution of plant sap. In this study, a moderate correlation was found between the colour of white cabbage head leaves and the number of adult thrips found inside the head. This correlation does not prove a causal relationship between the two variables, but it has been proved that yellow traps are more attractive to onion thrips than green or greenish-yellow ones (Kirk, 1984; Czencz, 1987; Szénási et al., 2001). Therefore we concluded that the yellowish head-leaf colour of susceptible varieties might have been the cause of the observed thrips preference. The intensity of reflectance at wavelengths smaller than $500 \mathrm{~nm}$ clearly differentiates the 6 varieties into two groups. The group of resistant varieties has greater reflectance intensity than the group of susceptible ones (Fig. 1). Since Kirk (1984) found that a white trap with UV reflection is a lot less attractive than the same white trap without UV reflectance and this trend continues in the UV part of their reflectance spectra, then the greater reflectance intensity might also contribute to the discrimination of resistant varieties as hosts by thrips.

\section{Acknowledgements}

We are grateful to all employees of the Department of Entomology at the Corvinus University of Budapest for their significant contribution to this study. This study was supported by the National Office for Research and Technology from the Research and Technology Innovation Fund. 


\section{Literature}

Andaloro, J. T., Hoy, C. W., Rose, K. B. and Shelton, A. M. (1983): Evaluation of insecticide usage in the New York. Processing-Cabbage Pest Management Program. J. of Economic Entomology 76, 1121-1124.

Czencz, K. (1987): The role of coloured traps in collecting thrips fauna. In: J. Holman, J. Pelikan, A. F. G. Dixon and L. Weisman (eds): Population Structure, Genetics and Taxonomy of Aphids and Thysanoptera. Proceedings of International Symposia, held at Smolenice, Czechoslovakia, September 9-14, 1985. SPB Academic Publishing, The Hague, pp. 426-435.

Dalchow, J. and Dern, R. (1983): Schäden an Kohl durch Zwiebelthrips (Thrips tabaci Lindeman 1888) und Kohlrübenthrips (Thrips angusticeps Uzel 1895) in Hessen. Gesunde Pflanzen 35, 235-237.

Ellis, P. R., Kazantzidou, E., Kahrer, A., Hildenhargen, R. and Hommes, M. (1994): Preliminary field studies of the resistance of cabbage to Thrips tabaci in three countries in Europe. Bulletin OILB/SPROP 17, 102-108.

Fail, J. (2006): Fejeskáposzta-fajták ellenállósága a dohánytripsszel szemben. (Resistance of white cabbage varieties to the onion thrips). Zöldségtermesztés 37, 21-27.

Fail, J., Pénzes, B., Szani, Sz. and Hudák, K. (2002): Dohánytripsz-ellenálló fejes káposzta fajták. (Onion thrips resistant white cabbage varieties). Növényvédelem 38, 561-570.

Fail, J., Pénzes, B. and Szani, Sz. (2003): Fejes káposzta-fajták dohánytripsz-ellenállósága. (Resistance of white cabbage varieties against the onion thrips (Thrips tabaci LIND.). Kertgazdaság 35, 44-52.

Garamvölgyi, P., Fail, J. and Pénzes, B. (2004): Pesticide-free protection of white cabbage against Thrips tabaci Lindeman. Acta Phytopathol. Entomol. Hung. 39, 187-192.

Giessmann, H. J. (1988): Zum Schadauftreten von Thrips tabaci an Kopfkohl für die Lagerung. Nachrichtenblatt für den Pflanzenschutz in der DDR 42, 109-110.

Herold, D. and Stengel, B. (1993): Les thrips sur chou à choucroute. Une situation inquiétante en Alsace. PHM Revue Horticole 336, 51-55.

Hoy, C. W. and Glenister, C. S. (1991): Releasing Amblyseius spp. (Acarina: Phytoseiidae) to control Thrips tabaci (Thysanoptera: Thripidae) on cabbage. Entomophaga 36, 561-573.

Kahrer, A. (1992): Monitoring the timing of peak flight activity of Thrips tabaci in cabbage fields. Bulletin IOBC/SROP 15, 28-35.

Kahrer, A. (1994): The flight activity of Thrips tabaci (Lind.) in relation to cabbage and cereal crops. Bulletin IOBC/SROP 17, 12-16.

Kirk, W. D. J. (1984): Ecologically selective coloured traps. Ecological Entomology 9, 35-41.

Kogan, M. and Ortman, E. F. (1978): Antixenosis - a new term proposed to define Painter's "nonpreference" modality of resistance. Bulletin of the Entomological Society of America 24, 175-176.

Kretschmer, M. (1984): Kohlthripse sortenspezifisch. Gemüse 20, 130.

Kristóf, L.né and Pénzes, B. (1984): Parás szemölcsök fejeskáposztán (Suberized verrucae on cabbage). Kertészet és Szőlészet 33, 9.

Kristóf, L.né, Pénzes, B. and Szani, Sz. (1988): A dohánytripsz (Thrips tabaci) kártétele káposztaféléken. (Damage of Thrips tabaci LIND. on cole crops). "Lippay János” Tudományos Ülésszak előadásainak és posztereinek összefoglalói, 1988. november. In: G. Geday (ed.). Kertészeti és Élelmiszeripari Egyetem Kiadványai, Budapest, pp. 193-194.

Legutowska, H. (1997): Thrips on cabbage crops in Poland. Biuletyn Warzywniczy 47, 55-62.

Mustafa, T. M. (1986): Spatial distribution of onion thrips and cabbage aphid on and response to some cruciferous crop plants. J. of Plant Diseases and Protection 93, 271-277.

North, R. C. and Shelton, A. M. (1986a): Ecology of Thysanoptera within cabbage fields. Environmental Entomology 15, 520-526.

North, R. C. and Shelton, A. M. (1986b): Colonization and intraplant distribution of Thrips tabaci (Thysanoptera: Thripidae) on cabbage. J. of Economic Entomology 79, 219-223.

Painter, R. H. (1941): The economic value and biologic significance of insect resistance in plant. J. of Economic Entomology 34, 360-367. 
Pénzes, B. and Szani, Sz. (1990): Fejeskáposzta fajták tripszérzékenysége. (Thrips susceptibility of garden cabbage varieties). "Lippay János” Tudományos Ülésszak előadásainak és posztereinek összefoglalói, 1990. november 10. Növényvédelmi szekció. In: Zalainé, K. E. (ed.). Kertészeti és Élelmiszeripari Egyetem Kiadványai, Budapest. 203 p.

Pénzes, B. and Szani, Sz. (1992a): A fajta szerepe a dohánytripsz (Thrips tabaci Lind.) kártételének kialakulásában. (The role of variety in development of thrips damage on cabbage). „Lippay János“ Tudományos ülésszak előadásai és poszterei. In: P. Voit (ed.). Kertészeti Egyetem Kiadványai, Budapest, Kertészet, Növényvédelmi szekció, pp. 529-531.

Pénzes, B. and Szani, Sz. (1992b): A dohánytripsz (Thrips tabaci) kártétele fejeskáposzta fajtákon. (The damage of onion thrips /Thrips tabaci/ on white cabbage varieties). Növényvédelmi Tudomanyos Napok, Budapest, p. 56.

Pénzes, B., Szani, Sz. and Ferenczy, A. (1996): Damage of Thrips tabaci on cabbage varieties in Hungary. Supplement of Folia Entomol. Hung. 52, 127-137.

Pénzes, B., Szani, Sz. and Ferenczy, A. (1998): A dohánytripsz kártétele fejes káposztán. (The damage of tobacco thrips on common white cabbage). Növényvédelem 34, 67-73.

Pénzes, B., Szani, Sz., Fail, J., Pap, J. and Ferenczy, A. (2000): A fajtahasználat szerepe a dohánytripsz (Thrips tabaci Lind.) elleni védelemben. (The role of variety employment in protection against the onion thrips (Thrips tabaci LIND.). "Lippay János-Vas Károly” Tudományos Ülésszak, Budapest 2000. November 6-7., Növényvédelmi Szekció, pp. 436-437.

Shelton, A. M. and North, R. C. (1986): Species composition and phenology of Thysanoptera within field crops adjacent to cabbage fields. Environmental Entomology 15, 513-519.

Shelton, A. M., Becker, R. F. and Andaloro, J. T. (1983): Varietal resistance to onion thrips (Thysanoptera: Thripidae) in processing cabbage. J. of Economic Entomology 76, 85-86.

Shelton, A. M., Hoy, C. W., North, R. C., Dickson, M. H. and Barnard, J. (1988): Analysis of resistance in cabbage varieties to damage by Lepidoptera and Thysanoptera. J. of Economic Entomology 81, 634-640.

Shelton, A. M., Stamer, J. R., Wilsey, W. T., Stoyla, B. O. and Andaloro, J. T. (1982): Onion thrips (Thysanoptera: Thripidae) damage and contamination in sauerkraut. J. of Economic Entomology 75, 492-494.

Shelton, A. M., Wilsey, W. T. and Schmaedick, M. A. (1998): Management of onion thrips (Thysanoptera: Thripidae) on cabbage by using plant resistance and insecticides. J. of Economic Entomology 91, 329-333.

Stoner, K. A. and Shelton, A. M. (1988a): Effect of planting date and timing of growth stages on damage to cabbage by onion thrips (Thysanoptera: Thripidae). J. of Economic Entomology 81, 1186-1189.

Stoner, K. A. and Shelton, A. M. (1988b): Influence of variety on abundance and within-plant distribution of onion thrips (Thysanoptera: Thripidae) on cabbage. J. of Economic Entomology 81, 1190-1195.

Stoner, K. A. and Shelton, A. M. (1988c): Role of nonpreference in the resistance of cabbage varieties to the onion thrips (Thysanoptera: Thripidae). J. of Economic Entomology 81, 1062-1067.

Szénási, Á., Jenser, G. and Zana, J. (2001): Investigation on the colour preference of Thrips tabaci Lindeman (Thysanoptera: Thripidae). Acta Phytopathol. et Entomol. Hung. 36, 207-211.

Trdan, S., Žnidarčič, D., Zlatič, E. and Jerman, J. (2004): Correlation between epicuticular wax content in the leaves of early white cabbage (Brassica oleracea L. var. capitata) and damage caused by Thrips tabaci Lindeman (Thysanoptera: Thripidae). Acta Phytopathol. et Entomol. Hung. 39, 173-185.

Trdan, S., Milevoj, L., Žežlina, I., Raspudić, E., Andjus, L., Vidrih, M., Bergant, K., Valič, N. and Žnidarčič, D. (2005): Feeding damage by onion thrips, Thrips tabaci Lindeman (Thysanoptera: Thripidae), on early white cabbage grown under insecticide-free conditions. African Entomology 13, 85-95. 